\title{
Effects of Plant Essential Oils on Vitamin C, Malondialdehyde and Some Biochemical Parameters of Rats*
}

\section{qAuthor(s)}

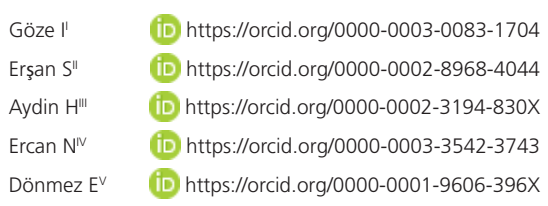

Niğde Ömer Halisdemir University Faculty of Medicine Department of Biochemistry.

Cumhuriyet University Faculty of Engineering Department of Chemistry Engineering.

III Faculty of Medicine Department of Biochemistry.

IV Faculty of Veterinary Medicine Department of Biochemistry.

Faculty of Science Department of Biology, Sivas, Turkey.

* Part of the present study was presented in TBD Biochemical Days, 2-5 November 2016, Sivas, Turkey.

\section{-Mail Address}

Corresponding author e-mail address Associate. Prof. Nazlı Ercan Cumhuriyet University Faculty of Veterinary Department of Biochemistry, Sivas, Turkey.

Phone: 0 (346) 21910 10-2575

Email: nazliercan@yahoo.com

\section{- Keywords}

Origanumminutiflorum O Schwarz-PH Davis, Juniperusexcelca Bieb.subsp.excelca, essential oil, Vitamin C, malondialdehyde, enzyme.

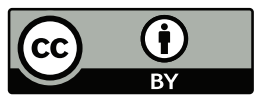

Submitted: 07/February/2018 Approved: 18/August/2018

\section{ABSTRACT}

The aim of this study was to determine the $\mathrm{LD}_{30}$ values of the essential oils of Origanum minutiflorum He Schwarz-PH Davis (OM) and Juniperus excelca by Bieb.subsp. Excel (JE) in vivo investigation on the effects of malondialdehyde (MDA), vitamin $C$ and some biochemical parameters. In this, study the essential oils of OM and JE plants were used. $L_{50}$ values of the essential oils were determined by using rats. OM $(n=10), J E(n=10)$, carvacrol $(n=10)$ which dissolve in olive oil were used as experimental group and as control group saline (SF) $(n=8)$ and solvent Olive oil $(n=10)$ were used and applied intraperitoneal on rats for 12 days in $\mathrm{LD}_{30}$ dosages. In the end of 12 days, Vit-C, malondialdehyde (MDA) and routine biochemical analyses were studied on their heart bloods. The difference in the levels of MDA and Vit- $C$ was found significant among the groups $(p<0.005)$. When the biochemical parameters of the groups were compared, all differences in all test were found significant $(p<0.005)$ except for creatinine $(p>0.005)$. When the values are put to paired comparison, the differences between groups were found statistically significant $(p<0.005)$.OM and JE has led to significant changes in all lipid peroxidation and enzyme levels.

\section{INTRODUCTION}

Although different types of plant extracts have already been studied, essential oils of plants have recently attracted the attention of researchers due to their antimicrobial and antioxidant characteristics for possible use for pharmaceutical purposes and as preservatives for fresh and processed foods (Sökmen et al., 2004).

The genus Origanum belongs to the Lamiaceae family, and has 41 species representing 52 taxa globally, and 23 species representing 32 taxa in Turkey (Başer, 2002). The most common chemical component of Origanum spp. essential oil is carvacrol (Kirimer et al., 1995; Başer, 2002; Baydar, 2005). Origanum minutiflorum O Schwarz-PH Davis (OM) is found worldwide and it is an endemic species in mountainous regions of Turkey, where it is commonly used in folk medicine (Baydar,2005; Davis et al., 1998). Origanum has been found to have antimicrobial (Vardar-Ünlü et al., 2007), antigenotoxic (Ipek et al., 2005), antibacterial, antifungal, and anti-angiogenic properties (Paster et al., 1995; Göze et al., 2016). In addition, it is used in the pharmaceutical, cosmetic, and soap industries (Farag et al., 1989; Souleles, 1991).

There are about 70 species of Juniperus L. (Cupressaceae) in the world. Juniperus speciesare represented by 10 taxa, with 7 subtypes of Juniperus excelca Bieb.subsp.excelca (JE)(gray tall juniper) identified in Turkey. Studies showed that one of its active ingredients is alphapinene (Ataş et al., 2012; Göze et al., 2015). Juniperus spp essential oils have been used in the cosmetic industry as tar and it is commonly used 
for the treatment of bronchitis and colds (Yeşilada et al., 1995).

In literature, in-vitro studies about $\operatorname{OM}(9,15)$ and JE (Salido et al., 2002 ; Kim et al., 2008; Miceli et al., 2009; Lesjak et al., 2011; Göze et al., 2015 ) have been published, but no in-vivo studies on the essential oils of these plants were found.

This study aimed at determining the in-vivo effects of OM and JE essential oils on blood malondialdehyde (MDA) and vitamin C levels and on some biochemical parameters of rats.

\section{MATERIALS AND METHODS}

The OM (CUFH Voucher No. ED11003) plants and JE (CUFH Voucher No. ED11003) fruits received from Sütçüler district of Isparta province were dried under suitable conditions and the essential oils of this plant and fruits were obtained by water vapor distillation in aclevenger apparatus. The $\mathrm{LD}_{50}$ values of the essential oils were previously determined in mice (Mus musculus var.albino), and the $\mathrm{LD}_{30}$ values $/ \mathrm{kg}$ were calculated for rats (Rattus norvegicus var. albino) and tested (Approval from C.Ü Ethics Board for Experimental Animals No:61).

The study included five treatment groups: Group 1 (control) saline solution $(n=8)$, Group 2 (control) olive oil $(n=10)$, Group 30M ( $n=10)$, Group 4 carvacrol $(n=10)$, and Group 5 JE $(n=10)$. A Group 6, to evaluate the main active compound of JE, $\alpha$-pinene, was not included in the study because the animals cannot survive to $L^{30}$ doses. Pure olive oil was used of as solvent and diluent.

Rats were intraperitoneally injected with $L_{30}$ doses of the evaluated oils per $\mathrm{kg}$ of rat body weight for 12 days. In the end of 12 days, rats were sacrificed by cervical dislocation, and their heart blood was collected. In addition to routine biochemical analyses using a clinical biochemistry analyzer (Beckmansynchron LX20), vitamin C and MDA were spectrophotometrically analyzed (Spectro UV-VIS Double Beam PC Scanning).

MDA activity measurement. The specific product of the reaction of MDA with thiobarbituric acid (TBA) creates a colorful complex of $532 \mathrm{~nm}$ wavelength and gives maximum absorbance (Jain, 1988). The blood samples were read in a spectrophotometer (Spectro UV-VIS Double Beam PC Scanning) against its own absorption value at $532 \mathrm{~nm}$ wave length. The evaluation was made using a standard curve created as a result of MDA-TBA reaction. For each erythrocyte, suspension hemoglobin was analyzed, and therefore MDA levels were evaluated as $\mu \mathrm{mol} / \mathrm{g} \mathrm{Hb}$ for each $\mathrm{g}-\mathrm{Hb}$.
Hemoglobin analysis. The cyanmethemoglobin method was applied (Tietz, 1994) for hemoglobin analysis in erythrocyte suspension of the experimental and control groups.

Vitamin $C$ analysis. The method of 2,4-dinitrophenylhydrazine method was applied (Tietz, 1994). The absorbance of all tubes was read at 520 $\mathrm{nm}$ via spectrophotometer. Vitamin C concentration is expressed as $\mathrm{mg} / \mathrm{dL}$ plasma.

Biochemical parameters. Heart blood samples collected from rats both in control and experimental groups were centrifuged at $4000 \mathrm{rpm} / \mathrm{min}$ to obtain serum samples. Fasting blood glucose, cholesterol, high-density lipoprotein (HDL), blood urea nitrogen (BUN), creatinine, total protein, albumin, alkaline phosphatase (ALP), alanine transaminase (ALT), aspartate transaminase (AST), lactate dehydrogenase $(\mathrm{LDH})$, creatine kinase (CK), gamma glutamyl transferase (GGT), total bilirubin, direct bilirubin, chlorine $(\mathrm{Cl})$, sodium $(\mathrm{Na})$, and potassium $(\mathrm{K})$ levels were measured using reagents (Beckman Synchron) of the autoanalyzer BeckmanSynchronLX20.

The obtained data were entered in the statistical software SPSS (version 13.0) One-way analysis of variance (ANOVA) was used to determine the differences between multiple groups and to test the results of homogeneity. Kruskal Wallis was used in the test results that did not provide both at the same time. Wilcoxon Rank test and paired samples $T$ test were used for binary comparison (Aygül, 2005).

\section{RESULTS AND DISCUSSION}

The chemical composition of the $\mathrm{OM}$ oil was determined only the essential oil part defined by GCMS as $96.15 \%$, in which 34 compounds were found, out of which the highest concentration was carvacrol represented $79.34 \%$. The remaining part could not be defined by GC-MS. The chemical composition of JE was defined only the essential oil part by GC-MS as $91.35 \%$ and the rest of part could not be defined GC-MS. The major component with the highest concentration was $\alpha$-pinene (55.53\%).

All biochemical parameters were significantly influenced $(p<0.005)$ the treatments, except for creatinine $(p>0.005)$. When the group values were compared, the difference between the groups was statistically significant $(p<0.005)$. The results are shown in Table 1.

When the results of rats injected with OM, carvacrol and JE (Groups 3, 4, and 5, respectively) were compared 
Table 1 - Biochemical values of the evaluated groups.

\begin{tabular}{lccccccc}
\hline & $\begin{array}{c}\text { Group 1: } \\
\text { Saline }\end{array}$ & $\begin{array}{c}\text { Group 2: } \\
\text { Olive oil }\end{array}$ & $\begin{array}{c}\text { Group 3: } \\
\text { O. minutiflorum }\end{array}$ & $\begin{array}{c}\text { Group 4: } \\
\text { Carvacrol }\end{array}$ & $\begin{array}{c}\text { Group 5: } \\
\text { J.excelca }\end{array}$ & P & Significance \\
\hline Glucose & $137.8 \pm 9.57$ & $141.7 \pm 2.56$ & $103.4 \pm 9.92$ & $103.1 \pm 10.06$ & $112.6 \pm 16.97$ & 0000 & $<0.001$ \\
Cholesterol & $40.6 \pm 2.61$ & $43.6 \pm 7.25$ & $25.8 \pm 6.11$ & $47.7 \pm 8.21$ & $31.1 \pm 7.25$ & 0.000 & $<0.001$ \\
HDL & $28.20 \pm 2.38$ & $38.71 \pm 7.85$ & $20.80 \pm 4.15$ & $33.09 \pm 8.78$ & $20.50 \pm 3.88$ & 0.000 & $<0.001$ \\
BUN & $17.40 \pm 1.14$ & $18.87 \pm 4.64$ & $13.90 \pm 3.17$ & $20.81 \pm 2.63$ & $17.33 \pm 6.08$ & 0.000 & $<0.001$ \\
Creatinine & $0.41 \pm 0.06$ & $0.43 \pm 0.11$ & $0.34 \pm 0.05$ & $0.47 \pm 0.17$ & $0.40 \pm 0.06$ & 0.124 & $>0.05$ \\
T. protein & $6.18 \pm 0.72$ & $6.64 \pm 0.95$ & $4.45 \pm 0.69$ & $6.56 \pm 0.98$ & $5.58 \pm 0.50$ & 0.000 & $<0.001$ \\
Albumin & $1.20 \pm 0.59$ & $1.66 \pm 0.37$ & $0.99 \pm 0.16$ & $1.48 \pm 0.017$ & $1.10 \pm 0.13$ & 0.000 & $<0.001$ \\
AST & $68.40 \pm 7.64$ & $76.38 \pm 19.43$ & $274.20 \pm 15.92$ & $244.73 \pm 62.25$ & $227.00 \pm 15.79$ & 0.000 & $<0.001$ \\
ALT & $38.40 \pm 5.51$ & $43.25 \pm 6.67$ & $109.30 \pm 10.45$ & $73.09 \pm 17.77$ & $87.50 \pm 16.93$ & 0.000 & $<0.001$ \\
AST/ALT & 1.78 & 1.77 & 2.51 & 3.35 & 2.59 & - & - \\
LDH & $426.86 \pm 23.40$ & $1015.00 \pm 188.20$ & $323.10 \pm 39.89$ & $948.27 \pm 305.39$ & $1168.00 \pm 148.07$ & 0.000 & $<0.001$ \\
GGT & $5.60 \pm 1.517$ & $5.63 \pm 1.41$ & $16.80 \pm 2.66$ & $19.46 \pm 5.87$ & $10.67 \pm 2.73$ & 0.000 & $<0.001$ \\
T. bilirubin & $1.24 \pm 0.12$ & $0.71 \pm 0.21$ & $0.56 \pm 0.07$ & $1.29 \pm 0.47$ & $1.17 \pm 0.10$ & 0.000 & $<0.001$ \\
D. bilirubin & $0.21 \pm 0.05$ & $0.21 \pm 0.08$ & $0.18 \pm 0.10$ & $0.68 \pm 0.30$ & $0.27 \pm 0.10$ & 0.000 & $<0.001$ \\
MDA & $0.350 \pm 0.047$ & $0.286 \pm 0.34$ & $0.298 \pm 0.037$ & $0.245 \pm 0.042$ & $0.385 \pm 0.129$ & 0.005 & $<0.05$ \\
Vit-C & $1.52 \pm 0.08$ & $2.05+0.30$ & $3.71 \pm 2.13$ & $2.41 \pm 0.63$ & $2.65 \pm 1.18$ & 0.005 & $<0.05$ \\
\hline
\end{tabular}

with those obtained in the group given saline solution (Group 1), all three groups showed lower fasting blood glucose, and higher AST, ALT, AST/ALT, GGT and vitamin $C$ levels. Cholesterol, HDL, total protein, albumin, total bilirubin and direct bilirubin levels were lower in Groups 3 and 5, and higher in Group 4. BUN and creatinine levels were lower in Groups 3 and 5, and higher in Group 4. Group 3 showed higher LDH and MDA levels and Groups 4 and 5 lower levels.

Compared with the results obtained in the group fed olive oil, fasting blood glucose, HDL, LDH, T. Bil., D.Bil., T. protein and albumin levels decreased, while AST, ALT, AST/ALT, and vitamin C levels increased in the three groups. The levels of $L D H, T$. bilirubin and D. bilirubin increased only in Group 4 and 5. Groups 3 and 5 showed lower cholesterol, BUN, and creatinine levels, whereas higher levels of these indicators were determined in Group 4. Higher MDA levels were obtained in Group 3 and 5, but lower MDA levels in Group 4.

Carvacrol, the active ingredient of the OM injected in Group 3, was also administered in the Group 4. However, the different results obtained in Group 4 compared with Group 3 may be explained by the fact that the active agent was applied directly.

The water-soluble vitamin $C$ can turn the tocopheroxyl radical into $\alpha$-tocopherol again and trolox radicals into trolox. In other words, vitamin $C$ recovers the antioxidant properties of vitamin $E$, having an indirect antioxidant activity (Doba et al., 1985; Barclay et al., 1985). In the present study, vitamin C levels significantly increased in the groups injected with OM, carvacrol, and JE oils.
MDA is an indicator of oxidative stress, and its levels were statistically lower in the Groups 3 and 4 compared with Group1 $(p<0.005)$. This finding supports the strong antioxidant activity of carvacrol and OM, which main compound is carvacrol. High vitamin C levels and low MDA levels were determined the rats injected with carvacrol. Carvacrol, the main compound of OM essential oil, is a phenolic compound used in traditional medicine and as a spice, and has been shown to have strong antioxidant activity (Teissedre, Waterhouse, 2000; Botsoglou et al., 2003b; Skerget et al., 2005). Phenolic compounds release/donate the hydrogen of the hydroxyl groups located in aromatic rings to prevent lipids and biomolecules to be oxidized by free radicals. These compounds are strong antioxidants that eliminate free radicals (Rice-Evans et al., 1995), form complexes with metal ions (metal chelation), as prevent or minimize the formation of singlet oxygen (Farag et al., 1989; Aeschbach et al., 1994).

In a review on antidiabetic medicinal plants, Patel et al. (2012) stated that blood glucose level may decrease as a function of reduction in glucose absorption or in insulin sensitivity. Lemhadri et al. (2004) found out that Origanum vulgare extract significantly decreased blood glucose levels of diabetic rats without changing basal insulin level. The present study showed that blood glucose levels were reduced in the rats injected with $\mathrm{OM}$, carvacrol, and JE, supporting those findings $(p<0.005)$.

The parameters AST/ALT ratio, albumin, and bilirubin are important for evaluating liver basal steatosis and initial fibrosis scoring. (Konerman et al., 2014). Aspartate aminotransferase (AST)/alanine 
aminotransferase (ALT) ratios higher than 2 and high gamma glutamyl transpeptidase (GGT) activity levels indicate liver disease (Leung et al., 1986; De Bruyn, Graviss, 2001; Giannini et al., 2003). In the present study, the high AST, ALT, and GGT activity levels and AST/ALT ratios higher than 2 observed in Groups 3 to 5 suggest that the rats injected with OM, carvacrol, and JE experienced liver damage.

Among essential oils, thyme oil is the most widely used in traditional medicine. The active compounds of thyme oil, like thymol and carvacrol, have strong antimicrobial effects (Marino et al., 1999; Dorman \& Deans, 2000). Carvacrol breaks down proteins of the bacterial cell wall, deforming it, and disrupt the $\mathrm{pH}$ gradient, causing other ions, primarily $\mathrm{K}+$, to flow into extracellular fluid. Cymene, a biological precursor of carvacrol, accumulates in cytoplasmic membrane and excessively expands the cell wall, creating gaps in the phospholipid layers, allowing ions to flow into intercellular fluids. As a result, the bacterial cells, which cannot synthesize ATP, die. According to Ultee et al. (2002), this mode of action does not pose risk of residues in the foods from animals fed carvacrol, because no metabolic waste is generated.

It is difficult to use as essential oils as antibacterial food preservatives because of their unique and sharp smell. As required by the law, antibiotics and synthetic preservers cannot be added to animal feeds, and therefore, $\mathrm{OM}$ and $\mathrm{JE}$, which are widely grown in our country, may be used as an alternative that will also contribute to our economy. However, in order to prevent metabolic problems that may arise from excessive consumption of these types of herbs and oils, suitable dosages should be designated and used (Karma, 2005a; Tuncer, 2007).

Considering the results of previous research and of the present study, OM and JE plant oils may be effective and beneficial as animal feed additives or as a food preservative because they reduce blood glucose and cholesterol levels. However, the fact that they may cause liver damage and metabolic disorders cannot be disregarded.

\section{ACKNOWLEDGEMENTS}

Part of the present study was presented in TBD Biochemical Days, 2-5 November 2016, Sivas, Turkey.

\section{REFERENCES}

Aeschbach R, Loliger J, Scott BC, Murcia A, Butler J, HallWell B, Aruoma OI. Antioxidant actions of thymol, carvacrol, 6-gingerol, zingerone and hyroxytyrosol. Food and Chemical Toxicology 1994:32:31-36.
Anonim. Karma Yemlere Katılması ve Hayvanlara Yedirilmesi Yasak Olan Maddeler Hakkında Tebliğ. Tarım ve Köyişleri Bakanlığı. (2005a): Erişim tarihi 27.07.2017. Sayı:25847 Tebliğ No:2005/24. Resmi Gazete.

Ataş AD, Göze I, Alim A, Çetinus S, Durmuş N, et al. Chemical composition antioxidant antimicrobial and antispasmodic activities of the essential oil of Juniperus excelsa subsp Excelsa. Journal of Essential Oil Bearing Plants 2012;15(3):476-483.

Aygül A. Biyoistatistik. Emek Ofset. 3. baskı. Ankara; 2005

Barclay LRC, Locke SJ, MacNeil JM. Autoxidation in micelles. Synergism of vitamin $C$ with lipid-soluble vitamin $E$ and water-soluble Trolox. Canadian Journal of Chemistry 1985;63(2): 366-374.

Başer KHC. The turkish origanum species. In: Kintzios SE, editor. Oregano. The Genera Origanum and Lippia. London: Taylor and Francais; 2002. p.108-26.

Baydar $\mathrm{H}$. The effects of different harvest dates on essential oil content and essential oil composition in Origanum minutiflorum. Akdeniz Üniversitesi Ziraat Fakültesi Dergisi 2005: 18(2):175-178.

Botsoglou NA, Grigoropoulou SH, Bostoglou E, Govaris A, Papgeorgiou G. The efffects of dietary oregano essential oil and $\alpha$-tocopherylacetate on lipidoxidation in raw and cooked turkey during refrigerated storage. Meat Science 2003b;65:1193-120

Davis PH, Mil RR, Tan K. Flora of Turkey land the east Aegean islands. Edinburgh: Edinburgh at the University Press; 1998.

De Bruyn G, Graviss EA. A systematic review of the diagnostic accuracy of physical examination for the detection of cirrhosis. BMC Medical Informatic \& Decision Making 2001:1:6-10

Doba T, Burton GW, Ingold KV. Antioxidant and co-oxidant activity of vitamin $C$ or a water-solube vitamin $\mathrm{E}$ analogue, upon the peroxidation of aqueous multimellar phospholipid liposomes. Biochimica et Biophsyca Acta 1985:835:298-303.

Dorman HJD, Deans SG. Antimicrobial agents from plants: antibacterial activity of plant volatile oils. Journal of Applied Microbiology 2000;83:308-316

Farag RS, Bade AZMA, Hewedi FM, El-Baroty GSA. Antioxidant activity of some spice essential oils on linoleic acid oxidation in aqueous media. Journal of the American Oil Chemists' Society 1989:66:792-799.

Giannini E, Risso D, Botta F, Chiarbonello B, Fasoli A, Malfatti F, et al. Validity and clinical utility of the aspartate amino transferase-alanine amino transferase ratio in assessing disease severity and prognosis in patients with hepatitis $C$ virus-related chronic liver disease. Archives of Internal Medicine 2003:163(2):218-24.

Göze A, Göze I, Alim A, Saygın H, Alim BA. Investigation of effects of essential oil from berries of juniperus excelsa bieb subsp excelsa cupressaceae on angiogenesis in shell less chick embryo CAM culture. Journal of Essential Oil Bearing Plants 2015;18(5):1100-1107.

Göze I, Alim A, Ercan N, Vural N. In vitro antimicrobial and antioxidant activities and chemical composition of essential oils of the leaf and flower of Origanum minutiflorum O Schwarz et PH Davis. YayınYeri: Cumhuriyet Üniversitesi Sağlık Bilimleri Enstitüsü Dergisi; 2016. p.1723.

Ipek E, Zeytinoglu H, Okay S, Tuylu BA, Kürkçüoğlu M, Başer KHC. Genotoxicity and antigenotoxicity of Origanum oil and carvacrol evaluated by Ames Salmonella/microsomal test. Food Chemistry 2005:93:551-556.

Jain SK. Evidence for membrane lipid peroxidation during the in vivo aging of human erytrocytes. Biochemica Biophysica Acta 1988:(937):205210 . 
Kim SJ, Jung JY, Kim HW, Park T. Anti-obesity effects of Juniperus chinensis extractare associated within increased AMP-activated protein kinase expression and phosphorylation in the visceral adipose tissue of rats. Biological and Pharmaceutical Bulletin 2008:31(7):1415-21.

Kirimer N, Başer KHC, Tumen G. Carvacrol- richplants in Turkey. Chemistry of Natural Compounds 1995;31:37-41.

Konerman MA, Yapali S, Lok AS. Systematic review: identifying patients with chronic hepatitis $C$ in need of early treatment and intensive monitoring-predictors and predictive models of disease progression. Alimentary Pharmacology Therapeutics 2014;40(8):863-879.

Lemhadri A, Zeggwagh NA, Maghrani M, Jouad H, Eddouks M. Antihyperglycaemic activity of the aqueous extract of Origanum vulgare growing wild in Tafilaletregion. Journal of Ethnopharmacology 2004;92(2-3):251-6.

Lesjak MM, Beara IN, Orcic DZ, Anackov GT, Balog KJ, Franciskovic MM. Juniperus sibirica Burgsdorf. as a novel source of antioxidant and antiinflammatory agents. Food Chemistry 2011;124:850-6.

Leung NW, Farrant $P$, Peters TJ. Liver volume measurement by ultrasonography in normal subjects and alcoholic patients. Journal of Hepatology 1986;2:157-64.

Marıno M, Bersanı C, Comı G. Antimicrobial activity of the essential oil of thymus vulgaris $L$. measured using a bioimpedometric method. Journal of Food Protection 1999;62(9):1017-1023.

Miceli N, Trovato A, Dugo P, Cacciola F, Donato P, Marino A, et al. Comparative analysis of flavonoid profile, antioxidant and antimicrobial activity of the berries of Juniperus communis L. var. communis and Juniperus communis L. var. saxatilis Pall. from Turkey. Journal of Agriculture and Food Chemistry 2009;57:6570-6577.

Paster N, Menasherov M, David U, Juven B. Antifungal activity of oregano and thyme essential oils applied as fumigants against fungi attacking stored grain. Journal of Food Protection 1995;58:81-85.

Patel DK, Prasad SK, Kumar R, Hemalatha S. An overview on antidiabetic medicinal plants having insulin mimetic property. Asian Pacific Journal of Tropical Biomedicine 2012;2(4):320-330.

Rice-Evans CA, Miller NJ, Bolwell PG, Bramley PM, Pridham JB. The relative antioxidant activities of plant-derived polyphenolic flavonoids. Free Radical Research 1995;22(4):375-83
Salido S, Altarejos J, Nogueras M, Sanchez A, Pannecouque C, Witvrouw M. Chemical studies of essential oils of Juniperus oxycedrus subsp. badia. Journal of Ethnopharmacology 2002;81:129-134.

Seca AML, Silva AMS. The chemical composition of the Juniperus genus (1970-2004). In: Govil JN, Singh VK, editors. Recent progress in medicinal 199 plants. Phytomedicines. Houston: Studium Press LLC; 2006. v. 16, p.399-520

Skerget M, Kotnik P, Hadolin M, Hras AR, Simonic M, Knez Z. Phenols, proanthocyanidins, flavones and flavonols in some plant materials and their antioxidant activities. Food Chemistry 2005:89:191-198.

Sökmen M, Serkedjieva J, Daferera D, Gulluce M, Polissiou M, Tepe H, et al. In vitro antioxidant, antimicrobial, and antiviral activities of the essential oil and various extracts from herbal parts and callus cultures of Origanum acutidens. Journal of Agriculture and Food Chemistry 2004;52:3309.

Souleles $C$. Volatile constituent of Origanum dubium leaves and stem bark. Planta Medica 1991;57(1):77-78.

Teissedre PL, Waterhouse AL. Inhibition of oxidation of human lowdensity lipoproteins by phenolic substances in different essential oils varieties. Journal of Agriculture and Food Chemistry 2000;48:3801-3805.

Tietz NW. Textbook of clinical chemistry. $2^{\text {nd }}$ ed. Philadelphia: WB Sounders; 1994.

Tuncer HI. Karma yemlerde kullanimi yasaklanan hormon, antibiyotik, antikoksidiyal ve ilaçlar. Lalahan Hayvancilik Araştirma Enstitüsü Dergisi 2007;47(1):29-37.

Ultee A, Benn KHJ, Moezelaar R. The phenolic hydroxyl group of carvacrol is essential for action against the food-borne pathogen, Bacillus cereus. Applied Environmental Microbiology 2002;3:1561-1568.

Vardar-Ünlü G, Ünlü M, Dönmez E, Vural N. Chemical composition and in vitro antimicrobial activity of the essential oil of Origanum minutiflorum O Schwarz \& PH Davis. Journal of the Science Food and Agriculture 2007;87(2):255-259.

Yeşilada E, Honda G, Sezik E, Mamoru T, Tetruso F, Toshihiro T. Traditional medicine in Turkey. V. Folk medicine in the Inner Taurus mountains. Journal of Ethnopharmacology 1995;46:133-152. 
